\title{
Assessment of Indoor and Outdoor Radiation Levels and Human Health Risk in Sheda Science and Technology Complex and its Environ, Abuja, Nigeria
}

\author{
*JAMES, IU; MOSES, IF; AKUECHE, EC; KUWEN, RD
}

Nuclear Technology Centre, Nigeria Atomic Energy Commission, Sheda-Abuja,

*Corresponding Author Email: jamesfam2002@yahoo.com

\begin{abstract}
A study to assess the Indoor and Outdoor Background Ionizing Radiation (BIR) of Sheda Science and Technology Complex, Abuja has been conducted. An in-situ measurement using a portable factory calibrated radiation dose rate meter, Radiagem 2000, was used to ascertain the radiation level. The measured radiation dose rates were used to evaluate the radiological health hazards and radiation effective doses to different body organs using well established radiological relations. The results shows that the total Dose Rate (indoor and outdoor), the Total Annual Equivalent Dose (indoor and outdoor), total Annual Effective Dose Equivalent (indoor and outdoor) and the total Excess Lifetime Cancer Risk (indoor and outdoor) are $0.113 \pm 0.022(\mu \mathrm{Sv} / \mathrm{h}), 0.071 \pm 0.016(\mu \mathrm{Sv} / \mathrm{h}), 0.794 \pm 0.155 \mathrm{mSv} / \mathrm{y}, 0.0 .124 \pm 0.074 \mathrm{mSv} / \mathrm{y}$, $0.556 \pm 0.109 \mathrm{mSv} / \mathrm{y}, 0.087 \pm 0.020 \mathrm{mSv} / \mathrm{y}, 1.945 \pm 0.379,0.304 \pm 0.104$ respectively for the three zones. The dosage to organs received shows that the testes have the highest dose while the liver has the lowest dose (indoor and outdoor) for the three zones. Generally the study shows that the Annual Effective Dose Equivalents were within the permissible limits of 1 $\mathrm{mSv} / \mathrm{y}$ for general public exposure recommended by the (ICRP). Also, the effective doses to different body organs are all below the recommended limits of $1 \mathrm{mSv} / \mathrm{y}$. The calculated Excess Lifetime Cancer Risk values indicates that the chance of contacting cancer by workers and residents of the study area is not probable hence the study area could be said to be radiologically safe.
\end{abstract}

\section{DOI: https://dx.doi.org/10.4314/jasem.v24i1.2}

Copyright: Copyright $(\mathrm{C} 2020$ James et al. This is an open access article distributed under the Creative Commons Attribution License (CCL), which permits unrestricted use, distribution, and reproduction in any medium, provided the original work is properly cited.

Dates: Received: 30 November 2019; Revised: 20 December 2019; Accepted: 23 December 2019

Keywords: Ionizing Radiation, Equivalent Dose, Effective Dose, Excess Lifetime Cancer Risk.

We are all exposed to ionizing radiation from natural sources at all times. Natural background radiation is inevitably present in our environment. Natural Background radiation is the radiation of man's natural environment, consisting of what comes from Cosmic rays, the naturally radioactive elements of the earth and from within man's body (Nwankwo and Akoshile 2005, UNSCEAR 2000). Human beings are exposed to background radiation that stems both from natural and man-made sources. In general, approximately $85 \%$ of the annual total radiation dose of any person comes from natural radionuclides of both terrestrial and cosmogenic origin (Belivermis et al. 2010; UNSCEAR 2000). According to ((UNSCEAR 2000) the worldwide annual effective dose from natural sources is estimated to be $2.4 \mathrm{mSv}$. The earth's crust contains various radioactive isotopes such as uranium, thorium, radon, tritium, carbon, and potassium among others. These isotopes and their decayed products have differences in their half-lives, which emit various types of radiations such as alpha, beta and gamma rays. Additionally, cosmic radiation from the sun contributes to gamma rays surrounding the human body. Conversely, the controlled manmade-artificial background radiation results from several sources such as fallouts of weapons testing, radioactive waste, and the use of radioisotopes in radiation-therapy. Both controlled and uncontrolled sources of radiation may have undesired biological effects to living species (Orwa et al., 2012, James and Moses, 2014). Small traces of many naturally occurring radioactive materials are present in the human body. Radiation has been found to be beneficial on one hand and harmful on the other hand. An in-situ measurement of the background radiation level was carried out at the vicinity of three campuses of two major tertiary institutions in Minna, Niger State. The results of the investigation revealed that the average annual effective dose obtained was $0.189 \mathrm{mSv} / \mathrm{y}$ (Olarinoye et al., 2010). A study of the background radiation in Akwanga, Nasarawa State showed that the annual mean equivalent doses for indoor and outdoor backgrounds are $1.29 \pm 0.13$ and $0.31 \pm 0.14 \mathrm{mSv} / \mathrm{y}$ respectively (Sadiq and Agba, 2011). Determination of Absorbed and Effective Dose from Natural Background Radiation around a Nuclear Research Facility was carried out in Zaria (Mohammad et al., 2011). It was observed that the estimated total annual effective dose outdoor for the sites range from 27.3$79.9 \mu \mathrm{Sv} / \mathrm{y}$. Also the natural background radiation 
dose/dose rate has been investigated by many researchers in other parts of the world and a wide range of results are reported (Amiri et al., 2011). The 2011 Fukushima Daiichi nuclear disaster displaced thousands of people and its effects is still been felt even in places far from the site (Tanabe, 2011). The more radiation dose a person receives, the greater the chance of developing cancer. The cancer may not appear until many years after the radiation dose is received (typically 10-40 years) and there is no level below which we can say an exposure does not pose a risk to life (Avwiri et al., 2010). Evaluation of hazard indices is of immense importance as it will be very useful in evaluating the radiological impact, by estimating the likelihood of developing various health effects (risks) associated with radiation exposure in the study area. This paper presents the indoor and outdoor background gamma radiation level, the annual effective dose equivalent rate (AEDE) and the excess life time cancer risk (ELCR) for the occupationally exposed and non-occupationally exposed workers working and living within Sheda Science and Technology Complex, Sheda and the general public living around the complex.

\section{MATERIALS AND METHODS}

Study Area: This study was conducted in and around the Sheda Science and Technology Complex (SHESTCO), Abuja. It is located $70 \mathrm{~km}$ from the capital city Abuja. SHESTCO is located on Latitude $8^{0} \mathrm{~N}$ and Longitude $7^{0} \mathrm{E}$. The study area was delineated into 3 zones for easy coverage in the measurement with zone 1 and zone 2 classified as working area while zone 3 include both working and residential area as shown in Table 1.

Instrumentation: An in-situ approach of background radiation measurement was adopted and preferred to enable samples maintain their original environmental characteristics. A portable Dose rate meter, Radiagem 2000 was used for the measurement. The Radiagem 2000 portable Dose rate Meter is an excellent, portable multipurpose radiation meter for a wide range of applications.it is a survey meter that includes an energy-compensated Geiger-Muller tube that measures the dose equivalent. It is especially designed for situations where accurate measurements at low dose rate levels are of importance. The assessment was achieved using a factory calibrated Radiagem 2000 portable survey meter (SN: 4423, Canberra, France). The monitor was suspended in air at one meter above the ground level. Readings were obtained between the hours of 1200 and 1600 hours since the exposure rate meter has a maximum response to environmental radiation within these hours as recommended by NCRP (1976). Five readings were taken at each indoor and outdoor location and the mean values were recorded.

Table 1: Location and Classification of study area

\begin{tabular}{llll}
\hline S/N & Location & Code & Classification \\
\hline ZONE & Gamma Irradiation Facility & & \\
1 & Central Workshop & GIF & working \\
2 & Radioactive Waste management Facility & CWS & Working \\
3 & RWM & Working \\
4 & New Instrumentation Laboratory & NIL & Working \\
5 & Old Shestco Administrative Building & OSA & Working \\
6 & Power Supply Station & PSS & Working \\
ZONE 2 & & \\
7 & Warehouse & WHE & Working \\
8 & New Shestco Administrative Building & NSA & Working \\
9 & Researchers' Hostel and Conference Centre & RCC & Working \\
10 & Staff Clinic & SFC & Working \\
11 & Recreational Centre & RLC & Working \\
12 & Gate House & GEH & Working \\
ZONE 3 & & \\
13 & Chemistry Advanced Laboratory & CAL & Working \\
14 & Physics Advanced Laboratory & PAL & Working \\
15 & Biotechnology Advanced Laboratory & BAL & Working \\
16 & Staff Quarters 1 & SQ1 & Residential \\
17 & Staff Quarters 2 & SQ2 & Residential \\
18 & Staff Quarters 3 & SQ3 & Residential \\
\hline
\end{tabular}

Radiation Health Risk Assessment: Different known radiation health hazard indices analysis is been use in radiation studies to arrive at a better and safer conclusion on the health status of a radiated or irradiated person and environment (Avwiri et al., 2012).
Equivalent Dose: The indoor and outdoor data obtained from the in situ measurement for the three zones within the study area were processed for mean value by adding up all the raw data obtained for each location and divided by the number of data taken to get the mean value for the location. 
Annual Equivalent Dose (AEDR): The mean equivalent dose rate in $\mu \mathrm{Sv} / \mathrm{h}$ obtained from the processing of the in-situ measurement was used to calculate the corresponding annual equivalent dose rate in $\mathrm{mSv} / \mathrm{y}$ using the mathematical relation given by (Tayyeb et al., 2012)

$\operatorname{AEDR}(\mathrm{mSv} / \mathrm{y})=\delta \times \mu \times 24 \times 365 \times 10^{-3}$

Where: $\delta=$ Equivalent dose rate in micro Sievert per hour. $\mu=$ Occupancy factor

Hence for the calculation of the indoor and Outdoor of the annual equivalent dose rate we use the equations below

Annual Indoor Equivalent Dose Rate $(\mathrm{mSv} / \mathrm{y})=$ Indoor Equivalent dose rate $(\mu \mathrm{Sv} / \mathrm{h}) \times 8760(\mathrm{~h} / \mathrm{y}) \times 0.8$ (indoor occupancy factor) $\times 0.001$

Annual Outdoor Equivalent Dose Rate $(\mathrm{mSv} / \mathbf{y})=$ Outdoor Equivalent dose rate $(\mu \mathrm{Sv} / \mathrm{h}) \times 8760(\mathrm{~h} / \mathrm{y}) \times$ 0.2 (Outdoor occupancy factor) $\times 0.001$

Annual Effective Dose Equivalent (AEDE): Radiation absorbed dose is a measure of the amount of energy absorbed per unit mass. It quantifies the radiation energy that might be absorbed by a potentially exposed individual as a result of a specific exposure. For whole body exposure, the quantity effective dose equivalent is used to measure the whole body absorbed dose. The annual effective dose equivalent (AEDE) is used in radiation assessment and protection to quantify the whole body absorbed dose per year. To estimate the AEDE the conversion factor $(0.7 \mathrm{~Sv} / \mathrm{Gy})$ from absorbed dose rate in air in $\mathrm{nGy} / \mathrm{h}$ to effective dose rate in $\mathrm{mSv} / \mathrm{y}$ is used with indoor occupancy factor of 0.8 and outdoor occupancy factor of 0.2 . The AEDE was calculated using the following formulae (UNSCEAR, 2000, Etuk et al., 2017):

AEDE (Indoor) $(\mathrm{mSv} / \mathrm{y})=\mathrm{D}_{\text {in }}(\mathrm{nGy} / \mathrm{h}) \times 8760(\mathrm{~h}) \mathrm{x}$ $0.8 \times 0.7 \mathrm{~Sv} / \mathrm{Gy} \times 10^{-3}(4)$

Where

$D_{\text {in }}\left(\frac{n G y}{h}\right)=\frac{E D R I x(\mu S / y) \times 10^{-3}}{Q}$

Similarly, AEDE (Outdoor) $(\mathrm{mSv} / \mathrm{y})=\mathrm{D}_{\text {out }}(\mathrm{nGy} / \mathrm{h}) \times 8760(\mathrm{~h}) \times$ $0.2 \times 0.7 \mathrm{~Sv} / \mathrm{Gy} \times 10^{-3}$

Where,

$D_{\text {out }}\left(\frac{n G y}{h}\right)=\frac{E D R O x(\mu S / y) \times 10^{-3}}{Q}$
Where $\mathrm{Q}$ is the quality factor which equals unity

Excess Lifetime Cancer Risk (ELCR): This gives the probability of developing cancer over a lifetime at a given exposure level. The ELCR has been calculated using the following equation (Darwish et al., 2015):

$\mathrm{ELCR}=\mathrm{AEDE} \times \mathrm{DL} \times \mathrm{RF}$

Where DL is the duration of life (70 years average) and $\mathrm{RF}$ is the risk factor ( $\mathrm{Sv})$ i.e. fatal cancer risk per Sievert. For stochastic effects, the ICRP 106 used a value of $\mathrm{RF}=0.05$ for the public

Hence for the calculation of the Indoor and Outdoor ELCR we use the equations below

$$
\begin{aligned}
& \mathrm{ELCR} \text { (indoor) }=\mathrm{AEDE} \text { (indoor) } \times \mathrm{DL} \times \mathrm{RF} \\
& \mathrm{ELCR} \text { (outdoor) }=\mathrm{AEDE} \text { (outdoor) } \times \mathrm{DL} \times \mathrm{RF}
\end{aligned}
$$

Effective dose rate ( $D_{\text {organ }}$ ) to different body organs and tissues: The effective dose to organs ( $\left.\mathrm{D}_{\text {organ }}\right)$ estimates the amount of radiation dose intake to various body organs and tissues. The effective dose rate delivered to a particular organ can be calculated using the following relation (Darwich et al., 2015):

$\mathrm{D}_{\text {organ }}\left(\mathrm{mSv} \mathrm{y}^{-1}\right)=$ AEDE x F

For the Indoor and Outdoor $\mathrm{D}_{\text {organ }}$ we use,

$\mathrm{D}_{\text {organ }}\left(\mathrm{mSv}^{-1}\right)=\mathrm{O} \times \mathrm{AEDE} \times \mathrm{F}$

Where $\mathrm{O}$ is the occupancy factor 0.2 (indoor) and 0.8 (outdoor) and $\mathrm{F}$ is the conversion factor of organ dose from air dose.

\section{RESULTS AND DISCUSSION}

Equivalent Dose: The indoor and outdoor data obtained from the in situ measurement for the three zones within the study area were processed for mean value by adding up all the raw data obtained for each location and divided by the number of data taken to get the mean value for the location. The result is as shown in Tables 1-4.

Annual Equivalent Dose: The Annual Equivalent Dose rate for the three zones is shown in shown in (Tables 1-3). A summary of the Annual Equivalent Dose rate (Table 4) shows that the Indoor dose rate ranges from $0.102 \pm 0.021 \mu \mathrm{Sv} / \mathrm{h}$ to $0.134 \pm 0.024 \mu \mathrm{Sv} / \mathrm{h}$ with a mean of $0.113 \pm 0.022 \mu \mathrm{Sv} / \mathrm{h}$ and Outdoor dose rate ranges from $0.062 \pm 0.021 \mu \mathrm{Sv} / \mathrm{h}$ to $0.083 \pm 0.005$ $\mu \mathrm{Sv} / \mathrm{h}$ with a mean of $0.071 \pm 0.016 \mu \mathrm{Sv} / \mathrm{h}$. These values are below the standard background radiation of $0.133 \mu \mathrm{Sv} / \mathrm{h}$. 
Annual Effective Dose Equivalent (AEDE): The AEDE for the three zones is shown in shown in (Tables 1-3) and a comparison with the internationally recommended limit is shown in Figure 1. A summary of the AEDE (Table 4) shows that the Indoor AEDE ranges from $0.502 \pm 0.101 \mathrm{mSv} / \mathrm{y}$ to $0.656 \pm 0.120$ $\mathrm{mSv} / \mathrm{y}$ with a mean of $0.556 \pm 0.109 \mathrm{mSv} / \mathrm{y}$ and Outdoor AEDE ranges from $0.076 \pm 0.026 \mathrm{mSv} / \mathrm{y}$ to $0.101 \pm 0.006 \mathrm{mSv} / \mathrm{y}$ with a mean of $0.087 \pm 0.020$ $\mathrm{mSv} / \mathrm{y}$. These values are lower than the ICRP recommended limits of $1.0 \mathrm{mSv} / \mathrm{y}$ for the public and $20 \mathrm{mSv} / \mathrm{y}$ for occupationally exposed workers. This indicates that the studied areas are in good agreement with permissible limit and do not constitute any immediate radiological health effect on the workers and the general public due to background ionizing radiation (BIR) exposure. However, periodic assessment of activity concentration of natural radionuclides and BIR levels in the study area should be carried out in order to ensure that exposure to radiation within the areas is kept to as low as reasonably achievable.

Excess Lifetime Cancer Risk (ELCR): The excess lifetime cancer risk is used in radiation protection assessment to predict the probability of an individual developing cancer over his lifetime due to low radiation dose exposure, if it will occur at all. The ELCR for the three zones is shown in shown in (Tables 1-3) and a comparison with world average shown in Figure 2. A summary of the ELCR (Table 4) shows that the Outdoor ELCR ranges from $0.266 \times 10^{-3}$ to $0.355 \times 10^{-3}$ with a mean of $0.304 \times 10^{-3}$ which is 1.05 times higher than the world's average of $0.29 \times 10^{-3}$ (Qureshi et al., 2014). The Indoor ELCR ranges from $1.756 \times 10^{-3}$ to $2.295 \times 10^{-3}$ with a mean of $1.94510^{-3}$ which is 1.68 times higher than the world's average of $1.16 \times 10^{-3}$ (Qureshi et al., 2014). The total (ELCR) ranges from $2.07510^{-3}$ to $2.0561 \times 10^{-3}$ with a mean of $2.249 \times 10^{-3}$ which is 1.55 times higher than the world's average of $1.45 \times 10^{-3}$ (Qureshi et al., 2014). These low values for excess lifetime cancer risk indicates that the probability of cancer development by workers and residents who wish to spend all their life time in the area is very low. The ELCR values reported in this study are lower than those reported for industrial areas of Warri and Effurun, Delta State, Nigeria (Agbalagba. 2017), and also lower than those for the salt lake environment of Okposi Okwu and Uburu of Ebonyi State, Nigeria (Avwiri et al., 2016). It is also lower than the values from Emene Industrial Layout, Enugu (Ugbede and Benson, 2018), highly populated motor parks in Enugu State, Nigeria (Benson and Ugbede, 2018), Unity park, Uyo, Akwa Ibom state, Nigeria (Etuk et al., 2017) and river sediments from Northern Pakistan (Qureshi et al, 2014).

Effective dose rate ( $D_{\text {organ }}$ ) to different body organs and tissues: The result of the effective dose rate delivered to the different organs is presented in Figure 3 , with the F values for Lungs, Ovaries, Bone marrow, Testes, Kidneys, Liver and Whole body as 0.64, 0.58, $0.69,0.82,0.62,0.46$ and 0.68 respectively, obtained from ICRP [1996]. The estimated average $D_{\text {organ }}$ values for the lungs, ovaries, bone marrow, testes, kidney, liver and whole body due to radiation exposure and inhalation in the study area are 0.071, 0.064, $0.077,0.091,0.069,0.051,0.076$ for indoor and 0.045 , $0.040,0.048,0.057,0.043,0.032,0.047$ for outdoor respectively. These results are all below the international tolerable limits of $1.0 \mathrm{mSv} / \mathrm{y}$ (Agbalagba, 2017, Ugbede and Benson, 2018) which further shows that the radiation levels do not constitute any immediate health effect on workers and residents of the study area. From the results, it is concluded that the testes and liver have highest and lowest sensitivity to radiation respectively for indoor and outdoor. The relatively higher dose to the testes and low dose intake to the liver is justifiable from food nutrient absorption rate (Zaid et al., 2010). This show that the impact of exposure to BIR levels in the study area contributes insignificantly to the radiation dose to these organs of the adult. Similar conclusion has also been made by Darwish et al. (2015), Agbalagba (2017) and Ugbede and Benson, (2018).

\begin{tabular}{|c|c|c|c|c|c|c|c|c|c|}
\hline & $\begin{array}{l}\text { Location } \\
\text { Code }\end{array}$ & $\begin{array}{l}\text { AIDR } \\
(\mu \mathrm{Sv} / \mathrm{h})\end{array}$ & $\begin{array}{l}\text { AODR } \\
(\mu \mathrm{Sv} / \mathrm{h})\end{array}$ & $\begin{array}{l}\text { AEDI } \\
\mathbf{m S v} / \mathbf{y}\end{array}$ & $\begin{array}{l}\text { AEDO } \\
\mathrm{mSv} / \mathrm{y}\end{array}$ & $\begin{array}{l}\text { AEDEI } \\
(\mathrm{mSv} / \mathrm{y})\end{array}$ & $\begin{array}{l}\begin{array}{l}\text { AEDEO } \\
(\mathrm{mSv} / \mathrm{y})\end{array} \\
\end{array}$ & \begin{tabular}{|l|l|} 
ELCRI \\
$\left(\times 10^{-3}\right)$
\end{tabular} & $\begin{array}{l}\begin{array}{l}\text { ELCRO } \\
\left(\times 10^{-3}\right)\end{array} \\
\end{array}$ \\
\hline 1 & GIF & 0.090 & 0.080 & 0.631 & 0.140 & 0.4415 & 0.0981 & 1.5453 & 0.3434 \\
\hline 2 & CWS & 0.090 & 0.080 & 0.631 & 0.140 & 0.4415 & 0.0981 & 1.5453 & 0.3434 \\
\hline 3 & RWM & 0.090 & 0.080 & 0.631 & 0.140 & 0.4415 & 0.0981 & 1.5453 & 0.3434 \\
\hline 4 & NIF & 0.102 & 0.082 & 0.715 & 0.144 & 0.5004 & 0.1006 & 1.7513 & 0.3520 \\
\hline 5 & OSA & 0.099 & 0.082 & 0.692 & 0.144 & 0.4847 & 0.1006 & 1.6964 & 0.3520 \\
\hline \multirow[t]{2}{*}{6} & PSS & 0.143 & 0.092 & 1.002 & 0.161 & 0.7015 & 0.1128 & 2.4553 & 0.3949 \\
\hline & Mean Value & $0.102 \pm 0.021$ & $0.083 \pm 0.005$ & $0.717 \pm 0.144$ & $0.145 \pm 0.144$ & $0.502 \pm 0.101$ & $0.101 \pm 0.006$ & 1.756 & 0.355 \\
\hline
\end{tabular}




\begin{tabular}{|c|c|c|c|c|c|c|c|c|c|}
\hline & Location Code & $\begin{array}{l}\text { AIDR } \\
(\mu \mathrm{Sv} / \mathbf{h})\end{array}$ & $\begin{array}{l}\text { AODR } \\
(\mu \mathrm{Sv} / \mathrm{h})\end{array}$ & $\begin{array}{l}\text { AEDI } \\
\mathrm{mSv} / \mathrm{y}\end{array}$ & $\begin{array}{c}\text { AEDO } \\
\mathrm{mSv} / \mathrm{y}\end{array}$ & $\begin{array}{c}\text { AEDEI } \\
(\mathrm{Sv} / \mathbf{y})\end{array}$ & $\begin{array}{l}\text { AEDEO } \\
(\mathrm{mSv} / \mathrm{y})\end{array}$ & $\begin{array}{l}\text { ELCRI } \\
\left(\times 10^{-3}\right)\end{array}$ & $\begin{array}{l}\text { ELCRO } \\
\left.0^{-3}\right)\end{array}$ \\
\hline 1 & WHE & 0.110 & 0.090 & 0.771 & 0.158 & 0.5396 & 0.1104 & 1.8887 & 0.3863 \\
\hline 2 & NSA & 0.144 & 0.056 & 1.009 & 0.098 & 0.7064 & 0.0687 & 2.4724 & 0.2404 \\
\hline 3 & RHC & 0.176 & 0.080 & 1.233 & 0.140 & 0.8634 & 0.0981 & 3.0218 & 0.3434 \\
\hline 4 & SFC & 0.120 & 0.032 & 0.841 & 0.056 & 0.5887 & 0.0392 & 2.0604 & 0.1374 \\
\hline 5 & RLC & 0.132 & 0.064 & 0.925 & 0.112 & 0.6475 & 0.0785 & 2.2664 & 0.2747 \\
\hline \multirow[t]{2}{*}{6} & GHE & 0.120 & 0.050 & 0.841 & 0.088 & 0.5887 & 0.0613 & 2.0604 & 0.2146 \\
\hline & Mean values & $0.134 \pm 0.024$ & $0.062 \pm 0.021$ & $0.937 \pm 0.167$ & $0.109 \pm 0.037$ & $0.656 \pm 0.120$ & $0.076 \pm 0.026$ & 2.295 & 0.266 \\
\hline
\end{tabular}

\begin{tabular}{|c|c|c|c|c|c|c|c|c|c|}
\hline & Location Code & $\begin{array}{l}\text { AIDR } \\
(\mu \mathrm{Sv} / \mathrm{h})\end{array}$ & $\begin{array}{l}\text { AODR } \\
(\mu S v / h)\end{array}$ & $\begin{array}{l}\text { AEDI } \\
\mathrm{mSv} / \mathrm{y}\end{array}$ & $\begin{array}{l}\text { AEDO } \\
\mathrm{mSv} / \mathrm{y}\end{array}$ & $\begin{array}{c}\text { AEDEI } \\
(\mathrm{mSv} / \mathrm{y})\end{array}$ & $\begin{array}{l}\text { AEDEO } \\
(\mathrm{mSv} / \mathrm{y})\end{array}$ & $\begin{array}{l}\text { ELCRI } \\
\left(\times 10^{-3}\right)\end{array}$ & $\begin{array}{l}\text { ELCRO } \\
\left(\times 10^{-3}\right)\end{array}$ \\
\hline 1 & CAL & 0.090 & 0.034 & 0.631 & 0.060 & 0.4415 & 0.0417 & 1.5453 & 0.1459 \\
\hline 2 & PAL & 0.130 & 0.098 & 0.911 & 0.172 & 0.6377 & 0.1202 & 2.2320 & 0.4207 \\
\hline 3 & BAL & 0.080 & 0.060 & 0.561 & 0.105 & 0.3924 & 0.0736 & 1.3736 & 0.2575 \\
\hline 4 & SQ1 & 0.115 & 0.085 & 0.806 & 0.149 & 0.5641 & 0.1042 & 1.9745 & 0.3649 \\
\hline 5 & SQ2 & 0.084 & 0.056 & 0.589 & 0.098 & 0.4121 & 0.0687 & 1.4422 & 0.2404 \\
\hline \multirow{2}{*}{6} & SQ3 & 0.124 & 0.075 & 0.869 & 0.131 & 0.6083 & 0.0920 & 2.1290 & 0.3219 \\
\hline & Mean values & $0.104 \pm 0.022$ & $0.068 \pm 0.023$ & $0.728 \pm 0.153$ & $0.119 \pm 0.040$ & $0.509 \pm 0.107$ & $0.083 \pm 0.028$ & 1.783 & 0.292 \\
\hline
\end{tabular}

\begin{tabular}{|c|c|c|c|c|c|c|c|c|c|}
\hline $\begin{array}{l}\text { Location } \\
\text { Code }\end{array}$ & $\begin{array}{l}\text { AIDR } \\
(\mu \mathrm{Sv} / \mathbf{h})\end{array}$ & $\begin{array}{l}\text { AODR } \\
(\mu \mathrm{Sv} / \mathrm{h})\end{array}$ & AEDI mSv/y & AEDO mSv/y & $\begin{array}{l}\text { AEDEI } \\
(\mathrm{mSv} / \mathrm{y})\end{array}$ & $\begin{array}{l}\text { AEDEO } \\
(\mathrm{mSv} / \mathrm{y})\end{array}$ & $\begin{array}{l}\text { ELCRI } \\
\left(\mathbf{x 1 0}^{-3}\right)\end{array}$ & $\begin{array}{l}\text { ELCRO } \\
\left({\left.\mathrm{x} 10^{-3}\right)}\right.\end{array}$ & $\begin{array}{l}\text { TOTAL } \\
\text { ELCR }\end{array}$ \\
\hline ZONE 1 & $0.102 \pm 0.021$ & $0.083 \pm 0.005$ & $0.717 \pm 0.144$ & $0.145 \pm 0.144$ & $0.502 \pm 0.101$ & $0.101 \pm 0.006$ & 1.756 & 0.355 & 2.111 \\
\hline ZONE 2 & $0.134 \pm 0.024$ & $0.062 \pm 0.021$ & $0.937 \pm 0.167$ & $0.109 \pm 0.037$ & $0.656 \pm 0.120$ & $0.076 \pm 0.026$ & 2.295 & 0.266 & 2.561 \\
\hline ZONE 3 & $0.104 \pm 0.022$ & $0.068 \pm 0.023$ & $0.728 \pm 0.153$ & $0.119 \pm 0.040$ & $0.509 \pm 0.107$ & $0.083 \pm 0.028$ & 1.783 & 0.292 & 2.075 \\
\hline Mean & $0.113 \pm 0.022$ & $0.071 \pm 0.016$ & $0.794 \pm 0.155$ & $0.0 .124 \pm 0.074$ & $0.556 \pm 0.109$ & $0.087 \pm 0.020$ & $1.945 \pm 0.379$ & $0.304 \pm 0.104$ & $2.249 \pm 0.271$ \\
\hline
\end{tabular}

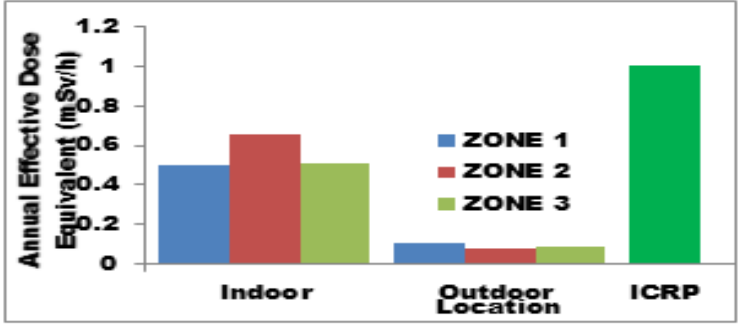

Fig 1: Annual Effective Dose Equivalent for Indoor and Outdoor for the three Zones

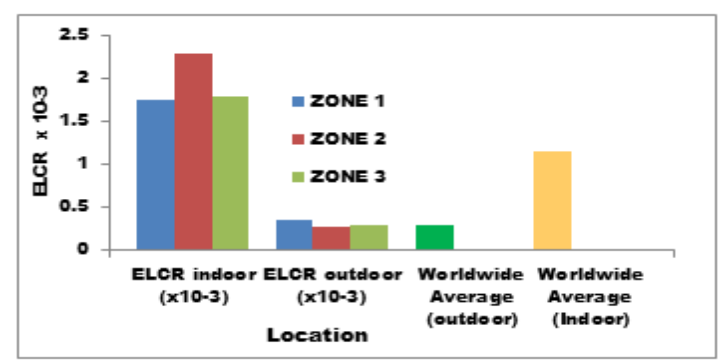

Fig 2: Excess Lifetime Cancer Risk for Indoor and Outdoor

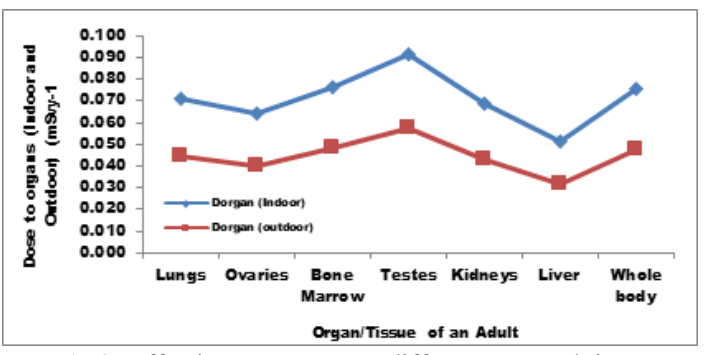

Fig 3: Effective Dose Rate to different Organs/Tissue

Conclusion: The qualitative and quantitative assessment of radiation exposure level and doses within an environment is an important aspect of radiation protection since human exposure to natural background radiation is a continuous and unavoidable feature of human existence. The present study has been designed in this regard to quantitatively assess the indoor and outdoor background radiation levels around Sheda Science and Technology Complex (SHESTCO) and its environ and to estimate their radiological impact on the workers, residents and the environment. The radiological assessment shows that the study area does not constitute any immediate radiological health effect on the workers and the general public due to BIR exposure. We recommend that a periodic assessment of activity concentration of natural radionuclides and BIR levels in the study area should be carried out to keep the radiation level to as low as reasonably achievable.

\section{REFERENCES}

Agbalagba OE (2017). Assessment of excess lifetime cancer risk from gamma radiation levels in Effurun and Warri city of Delta state, Nigeria. Journal of Taibah University for Science 11(3):367-380.

Amiri M; Abdi R; Shabestani MA (2011). Estimation of external natural background gamma ray doses to the population of Caspian coastal provinces in North of Iran. Iran. J. Radiat. Res., 9(3): 183-186.

Avwiri GO; Enyinna PI; Agbalagba EO (2010). Occupational Radiation Levels in Solid Mineral Producing Areas of Abia State, Nigeria. Scientia Africana, Vol. 9 (No.1), pp 93-97. 
Avwiri GO; Nwaka BU; Ononugbo CP (2016). Radiological health risk due to gamma dose rates around Okposi Okwu and Uburu salt lakes, Ebonyi State. International Journal of Emerging Research in Management and Technology 5(9):36-46.

Avwiri GO; Osimobi, JC; Agbalagba EO (2012),'Evaluation of radiation hazard indices and excess lifetime cancer risk due to natural radioactivity in soil profile of Udi and Ezeagu local government areas of Enugu State, Nigeria', Comprehensive Journal of Environmental and Earth Sciences. 1. 1-10.

Belivermis, M; Kılıç, N; Çotuk, Y; Topcuoğlu, S (2010). The effects of physicochemical properties on gamma emitting natural radionuclide levels in the soil profile of Istanbul. Environ Monit Assess. 163 (1-4): 15-26.

Benson, ID; Ugbede, FO (2018). Measurement of Background Ionizing Radiation And Evaluation Of Lifetime Cancer Risk In Highly Populated Motor Parks In Enugu City, Nigeria.” IOSR Journal of Applied Physics (IOSR-JAP), vol. 10, no. 3, pp. 7782.

Darwish DAE; Abul-Nasr KTM; El-Khayatt AM (2015) The assessment of natural radioactivity and its associated radiological hazards and dose parameters in granite samples from South Sinai, Egypt. Journal of Radiation Research and Applied Sciences 8 1725 .

Etuk SE; Essiett AA; Okechukwu E; Agbasi OE (2017) Measurement of Outdoor Ambient Radioactive Radiation and Evaluation of Radiation Indices and Excess Lifetime Cancer Risk within Uyo, Unity Park, Uyo, Nigeria JGEESI, 9(4): 1-9.

International Commission on Radiological Protection (ICRP) (1996). International Commission on Radiological Protection Age-dependent Doses to Members of the Public from Intake of Radionuclides. Part5: Compilation of Ingestion and Inhalation Coefficients. ICRP Publication 72, Pergamon Press, Oxford.

James, IU; Moses, IF (2014) Assessment of Radiation Dose Rate Levels in Selected Mechanic Workshops in Abuja, North Central Nigeria. Continental $J$. Applied Sciences 9 (1): 1 - 6.

Muhammad AM; Idris IF; Simon PM; Abdullahi SA (2011). Determination of Absorbed and Effective Dose from Natural Background Radiation around a Nuclear Research Facility. American Journal of Environmental Sciences 7 (2): 173-177.
NCRP. (1976): Report No. 050 - Environmental Radiation Measurements.

Nwankwo, LI; Akoshile, CO (2005). Background Radiation study of Offa Industrial area of Kwara State, Nigeria. J. App Sci. Environ. Management 9 (3): $95-98$

Olarinoye, IO: Sharifat, I: Baba-Kutigi, AN: Kolo, MT (2010). Measurement of background gamma radiation levels at two tertiary institutions in Minna, Nigeria. Journal of Applied Sciences, Environment and Management, 14 (1) 59-62.

Orwa JH; Mohamad A; Aziz B; Odayy Z; Ismail H; Solena A (2012). Measurements of the Environmental Natural Radiation in the Northern West Bank Governorate of Jenin. Journal of Science (JOS) Vol. 2, No. 1.

Qureshi AA; Tariq S; Din KU; Manzoor S; Calligaris C; Waheed A (2014) Evaluation of excessive lifetime cancer risk due to natural radioactivity in the rivers sediments of Northern Pakistan. Journal of Radiation Research and Applied Sciences, 7 (4): 438-447.

Sadiq A; Agba EH (2011). Background Radiation in Akwanga, Nigeria. FACTA UNIVERSITATIS Series: Working and Living Environmental Protection 8 (1): 7 - 11.

Tanabe. F (2011). Analysis of Core Melt Accident in Fukushima Daiichi-Unit 1 Nuclear Reactor. Journal of Nuclear Science and Technology, Vol 48 (8), 1135-1139.

Tayyeb AP: Hamed B; Maryam S (2012). Evaluation of High Level Environmental Background Radiation Areas and its Variation in Ramsar. Iranian Journal of Medical Physics Vol. 9, No. 2, 87-92.

Ugbede FO; Benson ID (2018), Assessment of outdoor radiation levels and radiological health hazards in Emene Industrial Layout of Enugu State, Nigeria. Int. J. Phys. Sci Vol. 13(20), pp. 265-272.

UNSCEAR (2000). United Nation Scientific Committee on the Effects of Atomic Radiation. Sources and effect of Ionizing radiation. Report to the general assembly with scientific annexes. United Nations; New York.

Zaid QA; Khled MA; Anas MA; Abdalmajeid MA. (2010). Measurement of Natural and Artificial radioactivity in Powder Milk corresponding Annual Effective Dose. Radiation Protection Dosimetry 138 (3): $278-283,2010$. 